\title{
The Public Perception of Traffic Jam in Kuala Lumpur Malaysia
}

\author{
${ }^{*}$ Lia Hasmita ${ }^{1}$ and Nur Afinie Binti Radzuan ${ }^{2}$ \\ ${ }^{1)}$ Graduate Student of Geography Education, Universitas Negeri Padang \\ e-mail: hasmitalia07@gmail.com \\ 2) Student of Geography, Malaya University, Malaysia \\ e-mail: afinieradzuan@gmail.com
}

*Corresponding Author, Received: September 14, 2018, Revised: October 21, 2018, Accepted: December 05, 2018

This is an open acces article distributed under the Creative Commons 4.0 Attribution License, wich permits unrestricted use, Distribution, and reproduction in any medium provided the original work is properly cited @2017 by author and Universitas Negeri Padang

\begin{abstract}
The purpose of this study was to analyze and describe the public perception of traffic jam in Kuala Lumpur, Malaysia, and analyze the factors that caused a traffic jam in Kuala Lumpur, Malaysia. This research is a qualitative descriptive study. Data collection techniques use observation, interviews and documentation as data collection instruments. Furthermore, the data will be analyzed using a qualitative descriptive analysis. The type of data used is primary data. Primary data in the form of observations, interviews and documentation. The results of this study revealed 1) public perception of traffic jam in Kuala Lumpur, Malaysia, the condition of traffic jam in Kuala Lumpur Malaysia is still quite severe, especially during rush hours, among others, in the morning when people leave for work, go to school and others etc., during the day during lunchtime, and in the afternoon when people will return home. Jam also occurs around tourist attractions in Kuala Lumpur, Malaysia. 2) Factors causing a traffic jam in Kuala Lumpur, Malaysia, caused by the increasing ownership of private vehicles, the low price of cars, public vehicles do not have their own lines. And the community is still reluctant to use public transportation.
\end{abstract}

Keywords: Traffic Jam, Causative Factors, Kuala Lumpur

\section{Introduction}

Transportation can be interpreted as the transfer of both goods and objects from the place of origin to another place. It can be said that if transportation does not exist then life does not exist because everything in the world does not move. There are three things in a nation to be large and prosperous, namely fertile land, hard work and smooth transportation of people and goods from the state to other parts (Nasution, 1996; Hermon et al., 2018). In the theory of urban development, it is also explained that the development of a city is influenced by the geographical conditions of the city and its transportation routes. In flat areas, it is possible to make cheap roads, railroads and canals, so that certain land uses, for example, industry extends extensively.

In general, big cities experience the same thing in the field of transportation, namely traffic jams on the highway. Population increase will encourage an increase in the need for land (Sadyohutomo 2008 in Umar, 2018; Hermon, 2010; Hermon, 2012; Hermon, 2015; Hermon, 2016; Hermon, 2017). An increase in population will also result in increasing the number of vehicles in urban areas causes problems with highways and traffic itself, especially on major roads. The existence of roadside activities often causes problems. Traffic jam often occurs in big cities, especially those that do not have good or adequate public transportation, also the imbalance between the availability of roads and the number of vehicles. 
Traffic jam problems are especially felt during busy hours both in the morning and evening, when people travel from home to work, school or other activities, and also when they return to their homes (Kasikoen and Atmaja, 2012). If the traffic volume on a road approaches the road capacity, traffic jam starts. Traffic jam increases when the traffic flow is so large that vehicles are very close to each other. Total jam occurs when vehicles must stop or move very slowly (Ofyar, 2000 in Kaisikoen 2012). Bottlenecks can also occur as a result of high activity around the road, especially for office land use, trade education and also the Central Business District (CBD).

Researchers about traffic by using real-world traffic incident data in transportation modelling, this study combines real-world traffic incident data into transportation simulations and analyzes the impact of road improvements, accidents and other types of incidents on the transportation system. Traffic incidents are modelled as a reduction in road capacity where transportation users can react by adjusting their transportation routes. Depending on the type of traffic incident, ie short-term vs. short-term effects, different behavioural reactions are applied that reflect different assumptions about the level of knowledge of transportation users. The results show that traffic incidents lead to an increase in average travel time per car journey of 5-7 minutes. In addition, over a long period of time, traffic incidents have a significant impact on the transportation system: On average working days, for almost half of all car trips, transportation users also travel on the road (segments) that are affected by traffic incident or cut a segment like that. Overall, this study highlights the importance of taking into account traffic incidents in transportation modelling (Kaddoura et al., 2018).

Traffic flow can be influenced by various factors. These factors are a topology, seasonal increases in road demand, signal lights, weather, etc. (Wei Liang Quek and Lock Yue Che, 2012). Understanding how each of these factors influences traffic flow is very important in avoiding undesirable phenomena, such as massive jam. Certain strategies, such as transportation planning are needed to prevent the growth of the entire urban area from disrupting the quality of life of those who live in it (Kargarfard et al., 2015; Murray and Wu, 2003).

In Malaysia and other developing countries, the quality of public transportation is one of the most common problems faced by governments and city planners. Providing high-quality public transportation is a challenge in Malaysia. In the face of consistent urban population growth over the past few years, the country has struggled to meet basic transportation requirements to maintain its economy and to encourage investment. Through Malaysia's development initiatives, the country has improved its public transportation system and reduced the number of private vehicles (Alemselati et al, 2015). As such, the state has contributed to the reduction of air and sound pollution, as well as reducing traffic jam.

Today, public transportation services have low reliability of arrival and departure times (long waiting times), low-speed travel, low frequency, and high levels of discomfort, especially on buses, where density is too frequent. These travel conditions should be modified to improve public transportation services, and increases are often associated with increased tariffs. Previous research on spike models to reduce traffic jam and improve public transportation in Malaysia shows that on average, transportation users receive a 35\% reduction in travel time and costs, and are willing to pay for an increase in parking fees of US \$0.62. Users who receive $45 \%$ of travel time and increased costs and are willing to pay an increase in RM1 parking fees have the lowest frequency of positive PAPs or (greater than zero) or WTA. The results of this study provide a clear vision of the modes of transportation favoured by users, which then help motivate them to switch from using private vehicles to public transportation, thereby reducing traffic jam (Alemselati et al., 2015). The main reasons for using private vehicles are as follows: less travel time, more privacy, better possibilities of point-to-point travel, and cost avoidance and other problems that are usually known to be caused by relying on public transportation. However, factors that might influence the choice of passengers to use public transportation are less known. Therefore, there are still traffic jams, even though there are many public transportation options, as well as adequate road conditions in Kuala Lumpur, Malaysia. Jam occurs especially during busy hours, for example at the time of departure of people working, school and others, the time of lunch and the time when people go home from work and so on. From this problem, it is expected that through this research can find out about a traffic jam in Kuala Lumpur, Malaysia, starting from public perceptions of traffic jam in Malaysia as well as factors that cause a traffic jam in Kuala Lumpur Malaysia. 


\section{Method}

This type of research is a qualitative descriptive study. Data collection techniques use observation interviews and documentation as data collection instruments. Data analysis used qualitative descriptive analysis. Data collected are primary data and secondary data. Primary data in the form of data obtained in the field is in the form of interviews and documentation observations (Hermon et al., 2008).

\section{Results and Discussion}

\section{Public perception of traffic jam in Kuala Lumpur, Malaysia}

To find out people's perceptions of traffic jam in Kuala Lumpur in Malaysia, the methods used are observation and interview methods. The results show that: The condition of traffic jam in Kuala Lumpur Malaysia based on interviews with the respondents they found the condition of traffic jam in Kuala Lumpur is still quite severe. Although there are already many types of modern transportation such as monorail trains, LRT trains, airport trains, buses to taxis. Jam that occurs normally during the hour - peak hours, for example at 6:30 until 9:30 pm, which is when the community will embark on activities such as going to work, school and so forth. Then from 16.30 to $10.00 \mathrm{AM}$, at these hours it is time for the community to return from their activities both at work and at school. Besides jam also occurred during the lunch hour, because at lunchtime people - people who work normally go out for lunch other than that on a rainy day is also common. Location of jam usually occurs in all downtown areas and also tourist areas, the beauty and natural diversity have a high appeal to increase tourist visits in a region. Malaysia has tourist destinations that attract tourists to visit from various countries (Hawkes et al, 1998 in Umar Iswandi, 2017). The occurrence of congestion here because in this area is the centre tourist jam that occurs normally because of the many visitors who come to cause a jam at these locations. The traffic jam that occurs in Kuala Lumpur is more severe if compared with Kajang or Putrajaya. Because in Kuala Lumpur is the centre of community activities. Although the traffic jam experienced by respondents varies. The amount of time the traffic jam experienced by the respondents also varied from 10-15 minutes, and even up to 40-45 minutes. Community feedback about the jam that jams made the trip to the destination of many stunted, time becomes inefficient that occurs only during working hours only, Thar caused a bad economic context, the problem of jam is a problem together so that the people in charge to have an awareness by starting from himself.

\section{Factors causing a traffic jam in Kuala Lumpur Malaysia}

The factors that affect traffic jam in Kuala Lumpur Malaysia are very large. The method used to determine the causes of traffic jam in Kuala Lumpur Malaysia is the observation and interview method. The results show that there are very many things that affect or cause a traffic jam in Kuala Lumpur, Malaysia. Based on the results of interviews with several respondents the first thing that caused a traffic jam in Kuala Lumpur Malaysia was due to an increase in the number of private vehicles which then affected the decrease in the number of public transport passengers. Malaysians prefer to use private vehicles because they can go directly to the destination. They used a little public transportation because they were reluctant to move from one public vehicle to another. In Malaysia, many issues and problems become obstacles to achieving a good quality of life in the city. With population growth not only increasing demand for job opportunities and demand for housing coupled with social facilities also increase the number of vehicles on the highway (Haryati, 2007), this situation is in line with what was expressed by respondents above the increasing number of vehicles as well with an increasing population, resulting in an increase in traffic jam in Kuala Lumpur, Malaysia Car prices in Malaysia are relatively cheap, plus cars produced by Malaysia themselves are cheap. So people are easy to buy a car because it's cheap. So on average, those who have worked have a private car, automatic jam is also increasing. The reason for using private vehicles when going to work and other activities are usually because they want to save time because riding public transportation is usually longer. In order not to be late to the destination, use a private vehicle to save time. In addition, there are many road accesses that are more like carrying a car.

Another factor that causes a traffic jam in Kuala Lumpur Malaysia is because the bus does not have its own lane. So when the traffic jams, the bus also gets stuck, so people become lazy to ride the bus. In 
addition, the bus departure time is still uncertain. The waiting time to move from one public vehicle to another public vehicle takes quite a long time as well as a factor causing people to be reluctant to take public transportation. Community behaviour also influences traffic jam. Malaysians are lazy to walk even though it's close. So if you take a public vehicle, it will require them to walk from the public transportation stop. So, therefore, they also prefer to use private vehicles everywhere. Save time and energy to get to the destination. In addition, the ease of obtaining public transportation in Malaysia is found in city centres such as in Kuala Lumpur, so sometimes it cannot provide satisfactory and maximum services to users. Unsatisfactory quality of service such as inconsistent travel schedules, overcrowded passengers that cause density on buses or monorail, bus trips that are too long, with regard to the scheduled bus trips and so on. Circumstances like this cause conditions that are uncomfortable for the user. Sometimes users try to switch on public vehicles, but the service offered is not satisfactory. However, to continue to use private vehicles it will be more difficult if you have to face long traffic jams, fatigue and so on.

In the case of traffic jam in Kuala Lumpur, Malaysia needs to see examples from developed countries that have a quality transportation system. As in Tokyo, Japan, which has a transportation network system that not only provides appropriate and fast but also quality comfort, in order to change people's perceptions of public transportation. And it is hoped that people can switch from private vehicles to public transport so that traffic jam decreases. Thus the traffic jam problem can be solved properly and wisely. The Malaysian kingdom is expected to work with certain parties such as bus ownership companies to provide first class service to users. Road Transportation Offices (JPJ) and Trade Reconciliation Institutions (LPKP), for example, may withdraw permits if the bus service does not meet the conditions set (Haryati and Sharifah, 2009). To overcome the problem of traffic jam in the city centre, a wise solution is to switch to public transportation. Public transport may be used as one of the most effective options to overcome the problem of traffic jam in the city centre. In dealing with traffic jam problems, if the quality of service can be improved such as good service to users, quality, competent, and fast and provide comfort to users, then this solution can reduce traffic jam problems. The convenience of using public transport will affect and contribute to the quality of life of the population, especially the population of the city center.

\section{Conclusion}

Public perception of traffic jam in Kuala Lumpur Malaysia, namely traffic jam in Kuala Lumpur, Malaysia is quite severe. Jam during peak hours such as at the time of departure and at the time of work. Jam also occurs when rain occurs. The locations of jam include the downtown areas of Kuala Lumpur and also tourist attractions. Factors affecting traffic jam in Kuala Lumpur Malaysia consist of various factors, including the main factor causing the jam due to the high level of private vehicle ownership, generally, people use private vehicles when they want to travel. The second is because of the low price of cars, so people are easy to buy cars. Then public vehicles do not have their own lanes, so when a traffic jam occurs, public vehicles also get stuck. So from some of these factors, people become lazy to ride public transportation. In addition to saving time also saves energy besides that they are also lazy to move - move from one public vehicle to another. So they prefer to use private vehicles because they can get straight to the destination. In addition, many road accesses that make it easier for people to choose their way when using private vehicles.

\section{References}

Alemselati, A.S. 2015. Using Spike Model To Reduce Traffic Jam and Improve Public Transportation in Malaysia. Selangor: Universiti Kebangsaan Malaysia, hal 60

Haryati, S. 2007. Persepsi Penduduk Terhadap tempat Tinggal dan Kualiti Hidup Masyarakat Bandar bangi. Program Pengurusan Perserikatan Pusatpengajian Siswazah. University Kebangsaan Malaysia

Haryati, S and S.M. S Musa. 2009. Pengangkutan di Bandar: Isu dan Penyelesaian. Jurnal of Technsocial. University Tun Hussein Onn Malaysia 
Hermon, D., Khairani., Daswirman., S. Karim., Dasrizal., and Triyatno. 2008. Metode dan Teknik Penelitian Geografi Tanah: Aplikasi Instrumen dan Acuan Penelitian Geografi Fisik. Yayasan Jihadul Khair Center.

Hermon, D. 2010. Geografi Lingkungan: Perubahan Lingkungan Global. UNP Press.

Hermon, D. 2012. Mitigasi Bencana Hidrometeorlogi: Banjir, Longsor, Degradasi Lahan, Ekologi, Kekeringan, dan Puting Beliung. UNP Press. Padang.

Hermon, D. 2015. Geografi Bencana Alam. Jakarta: PT RajaGrafindo Persada.

Hermon, D. 2016. Mitigasi Perubahan Iklim. Rajawali Pers (Radjagrafindo).

Hermon, D. 2017. Climate Change Mitigation. Rajawali Pers (Radjagrafindo).

Hermon, D., Y. Suasti., Ernawati., Afdhal., and H. Edial. 2018. Geografi: Geografi untuk SMU. Jurusan Geografi Universitas Negeri Padang.

Kaddoura, et al. 2018. Using Real World Traffic Insident Data In Transport Modeling. Procedia Computer Science 130 (2018) $880-885$

Kasikoen, Ken Martina et al. 2012. Upaya Penanganan Permasalahan Lalu Lintas di Ruas Jalan Karet Raya Kecamatan Cibodas. Jurnal Planesa Volume 3 No 1 Mei 2012. Hal 1

Nasution. H.M.N. 1996. Manajemen Transportasi, Penerbit Ghalia: Indonesia.

Quek, L. W and Chew, Y. L. 2014. Mechanism of Traffic Jams at Speed Bottlenecks. Procedia Computer Science Volume 29, 2014, Pages 289-298

Umar, I. 2017. Prioritas Pengembangan Objek Wisata di Kota Padang, Provinsi Sumatera Barat. Vol 6. No.1 Oktober 2017.

Umar, I., and Dewata, I. 2018. Arahan Kebijakan Mitigasi pada Zona Rawan Banjir Kabupaten Limapuluh Kota, Provinsi Sumatera Barat. Jurnal Pengelolaan Sumberdaya Alam dan Lingkungan (Journal of Natural Resources and Environmental Management), 8(2), 251-257. 